University of Nebraska - Lincoln

DigitalCommons@University of Nebraska - Lincoln

\title{
Function of Mentzelia nuda (Loasaceae) Postfloral Nectaries in Seed Defense
}

Kathleen H. Keeler

University of Nebraska - Lincoln, kkeeler1@unl.edu

Follow this and additional works at: https://digitalcommons.unl.edu/bioscifacpub

Part of the Botany Commons, and the Plant Biology Commons

Keeler, Kathleen H., "Function of Mentzelia nuda (Loasaceae) Postfloral Nectaries in Seed Defense" (1981). Faculty Publications in the Biological Sciences. 283.

https://digitalcommons.unl.edu/bioscifacpub/283

This Article is brought to you for free and open access by the Papers in the Biological Sciences at DigitalCommons@University of Nebraska - Lincoln. It has been accepted for inclusion in Faculty Publications in the Biological Sciences by an authorized administrator of DigitalCommons@University of Nebraska - Lincoln. 


\title{
FUNCTION OF MENTZELIA NUDA (LOASACEAE) POSTFLORAL NECTARIES IN SEED DEFENSE ${ }^{1}$
}

\author{
KathleEN H. KeEler \\ School of Life Sciences, University of Nebraska, Lincoln, Nebraska 68588
}

A B S T R A C T

\begin{abstract}
Mentzelia nuda is a coarse, short-lived perennial of the High Plains of North America. The flowers secrete nectar which serves as an attractant for pollinating bees. Postfloral nectar secretion attracts ants whose presence significantly enhances seed set. This is the first demonstration of advantage to postflowering activity of a floral nectary.
\end{abstract}

RECENT STUDIES of nectaries that lie outside the flower (generally called "extrafloral nectaries") indicate that, like floral nectaries, they are involved in plant-insect mutualism. Whereas floral nectaries facilitate outcrossing by rewarding pollinators, extrafloral nectaries attract insects, especially ants, whose activities decrease herbivore damage to the plant (Bentley, 1977a, b; Deuth, 1977; Keeler, 1977, 1980; Tilman, 1978; Inouye and Taylor, 1979; Koptur, 1979; O’Dowd, 1979; Pickett and Clark, 1979).

Floral nectar varies greatly in nectar content (Percival, 1962; Baker and Baker, 1973, 1975), and attracts a diversity of animals, including birds, bats, butterflies, moths, flies, bees, and beetles (Percival, 1965; Faegri and van der Pijl, 1979; Proctor and Yeo, 1973). Extrafloral nectaries have been shown to attract ants, wasps, flies and beetles (Putman, 1963; Keeler, 1978). When floral and extrafloral nectaries are functioning simultaneously on the same plant, visitors to the two nectary types are distinct (Keeler, 1977, 1980). This is probably a result of both structure and nectar quality. The visual and olfactory attractants of the flower are lacking at extrafloral nectaries, while the position of the extrafloral nectaries often excludes potential pollinators, especially vertebrates and large lepidoptera. Floral nectar has been shown to be attractive to ants (Feinsinger and Swarm, 1978; Schubart and Anderson, 1978), but the chemical content of floral and extrafloral nectar appears to differ (Keeler, 1977, 1980; Baker, Opler and Baker, 1978), suggesting differential attractiveness may exist (but see Koptur, 1979).

\footnotetext{
${ }^{1}$ Received for publication 9 February 1980; revision accepted 22 June 1980.

I thank I. Baker for identifying the nectar constituents, and W. La Berge, C. O'Brien, J. Ballard, and B. Ratcliffe for identifying the insects. I thank R. Schmidt for references to "post floral nectaries;' R. Kaul and M. Bolick provided moral support and taxonomic clarification; $\mathrm{S}$. Cantwell assisted with data analysis.
}

Nectaries that reward pollinators, but continue to function after the corolla has fallen and the fruit develops, have been described (Daumann, 1932, 1974; Bentley, 1977a; Faegri and van der Pijl, 1979), but their function has not been determined. The presence of a functioning nectary on the developing fruit may confer a selective advantage. This paper reports a study to test this hypothesis, using the floral and postfloral nectaries of Mentzelia nuda.

MeThods AND SITE-Mentzelia nuda (Pursh.) T.\&G. (Loasaceae) (Fig. 1, 2) is a tall (to $1 \mathrm{~m}$ ) coarse herb of disturbed sites from eastern Montana and the western Dakotas to west Texas, New Mexico and Arizona. It is a short-lived perennial and blooms from July to September.

This study was carried out at the Cedar Point Biological Station, Keith Co., Nebraska, in the summer of 1978 and 1979.

Nectar was collected with micropipettes and transferred onto filter paper. Nectar content was determined by I. Baker, Dept. of Botany, University of California, Berkeley.

Pollinators and herbivores were observed and collected. Identification was provided by B. Ratcliffe, Nebraska State Museum, Lincoln, and W. E. La Berge, Illinois Natural History Survey, Urbana. Weevils were identified by C. O'Brien, Florida $\mathrm{A}$ and $\mathrm{M}$ University, Tallahassee. J. Ballard, University of Nebraska, Lincoln, identified the ants. Voucher specimens are in the possession of the individuals who identified the insects and in the Nebraska State Museum.

Development of 87 marked fruits was followed to determine length of developmental period and natural levels of seed production.

The potential effect of ants was determined by banding with Tanglefoot resin to exclude ants from the plants. At the end of the growing season, ripe pods of experimental and control plants were collected and scored for damage 

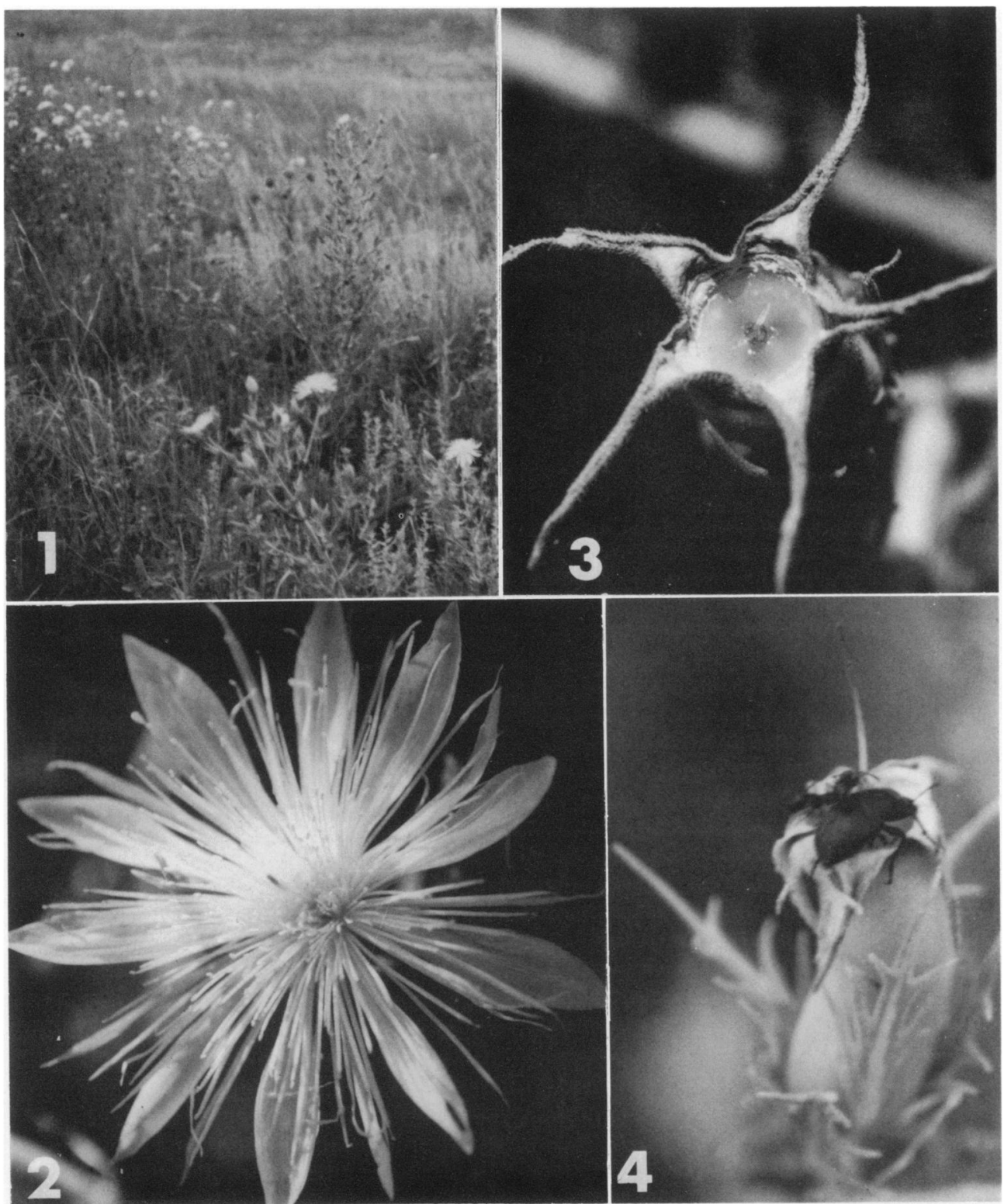

Fig. 1-4. 1. Mentzelia nuda at Arapaho Prairie, Arthur Co., Nebraska. Approximately $1700 \mathrm{hr}$, MDST, Aug., 1979. $\times 0.05$. 2. Flower of $M$. nuda. $\times 1$. 3. $M$. nuda capsule. Nectar is visible as the shiny area around the remnants of the style. $\times 1$. 4. Ants repelling beetle on $M$. nuda capsule. $\times 1$.

and seed set. Seeds were tiny and very numerous, so total seed production was estimated by weighing on a Mettler balance.

RESULTS-Mentzelia nuda flowers open daily at approximately $1600 \mathrm{hr}$ M.D.T. and close at dusk (ca. $2100 \mathrm{hr}$ ). Individual flowers open daily for about 6 days $(\bar{x}=6.1, n=32)$, after which the corolla falls from the enlarging capsules. Nectar is produced by nectariferous cells above the inferior ovary while the flower is open (Brown and Kaul, 1981) and for approximately half of the period of truit development (Fig. 3). Generally development of seeds requires 3 to 4 wk.

Mentzelia nuda appears to be an obligate outcrosser. This is inferred from lack of seed set under greenhouse conditions (Brown and Kaul, 1980) and from the fact that seed set per flower was highly variable: eight of 87 capsules studied never expanded, suggesting inadequate pollination. 
TABle 1. Pollen-bearing insect visitors of Mentzelia nuda flowers

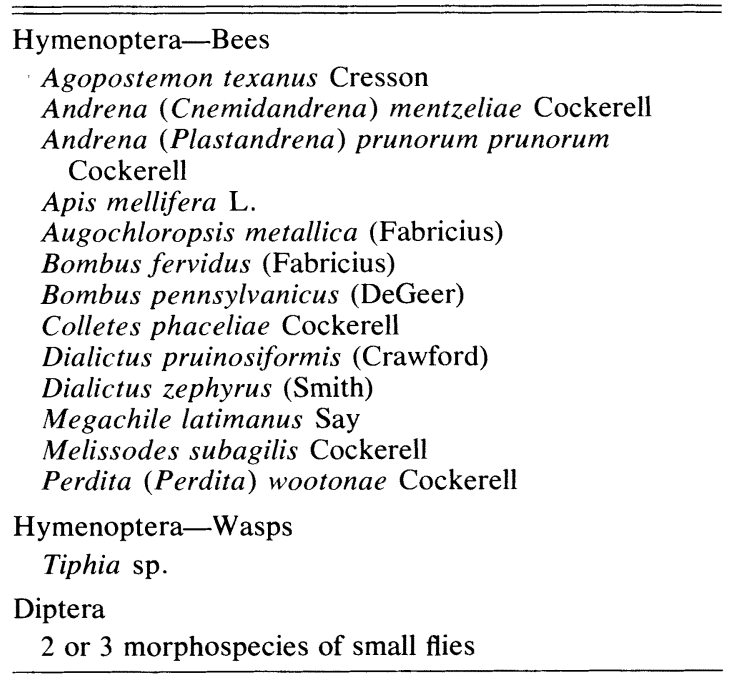

The only flower visitors seen were bees and flies (Table 1). Most of these visitors gathered nectar, becoming covered with pollen while burrowing among the stamens to reach the nectary. Andrena mentzeliae and Perdita wootonae are oligotrophic on Mentzelia (La Berge, pers. commun.) and abundant visitors to $M$. nuda; the others are generalists.

Plants in the study area produced from several thousand to 25,000 seeds each. At the same time there was much loss of developing fruit, of 87 individual capsules followed during this study, mature seeds developed in only 40 .

Nectar content is given in Tables 2 and 3. Floral and postfloral nectars have very similar composition. Certainly the differences are less marked than between most floral and extrafloral nectars (Keeler, 1977, 1980; Baker et al., 1978).

Rates of floral nectar production were not
TABle 3. Amino acid composition of Mentzelia nuda floral and postfloral nectar ${ }^{\mathrm{a}}$

\begin{tabular}{lcc}
\hline \hline \multicolumn{1}{c}{ Amino acid } & Floral & Postfloral \\
\hline alanine & 2 & $1-2$ \\
arginine & 1 & $?$ \\
asparagine & 3 & 1 \\
aspartic acid & 2 & $?$ \\
cysteine, etc. & 3 & 2 \\
glutamic acid & 3 & $?$ \\
glutamine & 2 & 1 \\
glycine & 1 & 1 \\
isoleucine & 1 & 1 \\
leucine & 1 & 1 \\
lycine & 1 & $?$ \\
methionine & 2 & $?$ \\
phenylalanine & 1 & 1 \\
proline & $3-4$ & $1-2$ \\
serine & 2 & $?$ \\
threonine & 1 & $?$ \\
tyrosine & 2 & 2 \\
valine & $1-2$ & 1
\end{tabular}

a Histidine scale of Baker and Baker (1973, 1975): $1=$ $7.58 \mu \mathrm{g} / \mathrm{ml} ; 2=15.16 \mu \mathrm{g} / \mathrm{ml} ; 3=30.32 \mu \mathrm{g} / \mathrm{ml}$.

obtained; the closely packed stamens made sampling without damaging the flower or blocking the pipette very difficult. Postfloral nectar production was about $0.1 \mu \mathrm{l} / 24 \mathrm{hr}$ on cut stalks. Field measurements of maximum nectar available at a single nectary was $1.2 \mu \mathrm{l}$ $(\bar{x}=0.4 ; \mathrm{SD}=0.364 ; n=18$ for floral nectaries) to $4.0 \mu \mathrm{l}(\bar{x}=0.87 ; \mathrm{SD}=1.10 ; n=$ 20) for postfloral nectaries.

The postfloral nectary functions for approximately 10 days after the corolla has fallen. During this period it is visited by ants. Of 100 plants with active postfloral nectaries, 43 had ants feeding at or near the capsule.

The mean number of ants on plants with ants present was 2.4, but 16 were seen on one plant, and most plants (24 of 43) had only one at the time of the survey. The ants taking $M$. nuda nectar were mostly small, e.g. Lasius neoniger

TABLE 2. Chemical content of Mentzelia nuda floral and postfloral nectar ${ }^{\mathrm{a}}$

\begin{tabular}{lccc}
\hline \hline \multicolumn{1}{c}{ Compound } & Floral & Post-floral & Test used \\
\hline Lipids & + & ++ & osmic acid \\
Phenolics & ++ & ++ & p-nitraniline \\
Alkaloids & slight + & + & Dragendorff \\
Protein & ca. $1.2 \mathrm{mg} / \mu \mathrm{l}$ & $\mathrm{ca} .1 .2 \mathrm{mg} / \mu \mathrm{l}$ & Brom-phenol \\
Organic acids & + & + & 2,6 -dinitrophenol-indolphenol \\
Relative proportions of sugars & & & \\
$\quad$ Maltose & & 0.016 & \\
Sucrose & 0.464 & 0.320 & \\
Glucose & 0.283 & 0.353 & \\
Fructose & 0.253 & 0.311 & \\
\hline
\end{tabular}

“Symbols: $+=$ present, $++=$ strongly present. 
TABLE 4. Damage to seed pods in ant-excluded and control plants; damage defined as any injury, distortion or insect hole ${ }^{\text {a }}$

\begin{tabular}{llcc}
\hline \hline Treatment & $\begin{array}{c}\text { Undamaged } \\
\text { capsules }\end{array}$ & $\begin{array}{c}\text { Damaged } \\
\text { capsules }\end{array}$ & $\begin{array}{c}\text { Total } \\
\text { capsules }\end{array}$ \\
\hline Ants present & $542(80 \%)$ & 134 & 676 \\
Ants excluded & $434(75 \%)$ & 141 & 575 \\
$\quad$ Total & 976 & 275 & \\
\hline
\end{tabular}

${ }^{a} \chi^{2}=4.00,0.05>P>0.025$, d.f. $=1$.

Emery, Dorymyrmex pyramidicus (Roger), Pheidole bicarinata bicarinata Mayr, but a few larger species were seen, e.g. Formica fusca group cinera lepida Wheeler and Formica microgyna group. No ants were seen on plants without nectar-producing pods. This difference is statistically significant from plants with postfloral nectar $\left(P \simeq 0.005 ; \chi^{2}=54.8\right.$, d.f. $=$ 1).

Ants are apparently physically prevented from taking floral nectar by the dense stamens. On flowers where beetles had eaten large numbers of the stamens, ants were observed at the floral nectary. Ants were never observed on nondamaged flowers.

Unlike the usual case with extrafloral nectaries, at least one individual of a pollinating species took postfloral nectar. A foraging worker of Apis mellifera went sequentially to at least 20 postfloral nectaries, at no time in that trip visiting the surrounding open flowers. On other days, individuals of $A$. mellifera were seen to visit $M$. nuda flowers, becoming covered with pollen.

The results of ant-exclusion experiments are given in Tables 4 and 5 . Both the comparison of insect damage to pods and the number of seeds produced between experimental and control plants are statistically significant.

One cause of seed loss was the larva of the moth Strymon melinus Hubner (Lycaenidae) which emerged from $M$. nuda capsules. Similarly, capsules frequently were found to contain the weevil Orthoris crotchi Lec (Curculionidae). Each had a characteristic pattern of

TABLE 5. Effect of excluding ants on seed set ${ }^{\mathrm{a}}$

\begin{tabular}{lcc}
\hline \multicolumn{1}{c}{ Treatment } & Good $^{\mathrm{b}}$ seed $(\mathrm{gm})^{\mathrm{c}}$ & Bad seed $(\mathrm{gm})$ \\
\hline Ants present & $17.44(84 \%)$ & 3.21 \\
Ants excluded & $12.33(72 \%)$ & 4.88 \\
\hline
\end{tabular}

\footnotetext{
${ }^{a} \chi^{2}=1309, P<0.001$, d.f. $=1$.

b) Herbivores generally consume the embryos of all or part of a column of seeds in the capsule; good seeds were those that had not been damaged; bad seeds were all others.

${ }^{c}$ Mean wgt. 1 seed: $0.0007 \mathrm{gm}$.
}

damage and they probably account for the majority of the damage to the collected seeds. Beetles were observed feeding on the capsule (Fig. 4). A fourth cause of seed loss was an unidentified green larva which fed on the seed capsules, burrowing in from the top, a position highly vulnerable to nectar-feeding ants.

Interaction of capsule-visiting ants with ovipositing or feeding herbivores must be inferred by analogy with other studies (e.g, Tilman, 1978; Inouye and Taylor, 1979; Pickett and Clark, 1979), but ants were observed to drive off one of a pair of large beetles feeding on capsules.

Discussion-The continuation of nectarflow after loss of the corolla is known in occasional species (Daumann, 1932, 1974; Bentley, 1977a; Faegri and van der Pijl, 1979), but no functional significance has been shown. These results suggest that the continued production of nectar after the end of flowering in Mentzelia nuda serves as a mechanism of seed protection. The fact that ant abundance on the plant dramatically increases when the postfloral nectar becomes available suggests that occasional ant foragers in the plant canopy can respond promptly to new food sources.

It would seem from the observations here that there is no restriction of ant visitation to floral nectar other than floral morphology. It is curious that so few flower-visiting bees foraged on the postfloral nectar. Perhaps pollinators require the corolla to attract them.

The continuation of nectar production following corolla drop is an energetically economical method of producing nectar-based seed defenses. However, it requires that such defense not be needed during flowering. Curiously, that seems to be true for Mentzelia nuda. Some damage occurred from large beetles that ate the stamens and sepals, whether the flower was open or closed, but generally, damage was light. By comparison, predation on the developing seeds had numerous sources.

\section{LITERATURE CITED}

BAKer, H. G., AND I. BAKer. 1973. Amino acids in nectar and their evolutionary significance. Nature 241: 543 545.

—, AND —. 1975. Studies of nectar-constitution and pollinator-plant coevolution. In L. E. Gilbert and P. Raven [eds.], Co-evolution of animals and plants, p. 100-140. University of Texas Press, Austin.

, P. A. Opler, AND I. BAKer. 1978. A comparison of the amino acid complements of floral and extrafloral nectaries. Bot. Gaz. 139: 322-332.

Bentley, B. L. 1977a. Extrafloral nectaries and protection by pugnacious bodyguards. Ann. Rev. Ecol. Syst. 8: $407-427$. 
1977b. The protective function of ants visiting the extra-floral nectaries of Bixa orellana (Bixaceae). J. Ecol. 65: 17-38.

Brown, D. K., AND R. B. KAUL. 1981. Floral structure and mechanism in Loasaceae. Amer. J. Bot. 68: 361-372.

DaumanN, E. 1932. Über postflorale Nectar abscheidungen. Beih. Bot. Centralbl. 49: 720-734.

1974. Zur Frage nach dem Vorkommen eines Septalnectariums bei Dicotyledonen. Preslia (Prague) 46: 97-109.

DEUTH, D. 1977. The function of extrafloral nectaries in Aphelandra deppeana Schl. \& Cham. (Acanthaceae) Brenesia 10/11: 135-145.

Elias, T. S., and H. Gelband. 1975. Nectar: its production and function in trumpet creeper. Science 189: 289-291.

FAegri, K., ANd L. VAN der PiJl. 1979. The principles of pollination ecology. 3rd edition, Pergamon Press, Oxford.

Feinsinger, P., ANd L. A. Swarm. 1978. How common are ant-repellent nectars? Biotropica 10: 238-239.

INOUYE, D. N., AND O. R. TAYLOR, JR. 1979. A temperate region plant-ant-seed predator system: consequences of extrafloral nectar secretion by Helianthella quinquenervis. Ecology 60: 1-7.

KeELER, K. H. 1977. The extrafloral nectaries of Ipomoea carnea (Convolvulaceae). Amer. J. Bot. 64: 1182-1188.
1978. Insects feeding at extrafloral nectaries of Ipomoea carnea (Convolvulaceae). Ent. News 89: 163-168.

1980. The extrafloral nectaries of Ipomoea leptophylla. (Convolvulaceae). Amer. J. Bot. 67: 216222.

Koptur, S. 1979. Facultative mutualism between weedy vetches bearing extra-floral nectaries and weedy ants in California. Amer. J. Bot. 66: 1061-1020.

O'DowD, D. J. 1979. Foliar nectar production and ant activity on a neotropical tree, Ochroma pyramidale. Oecologia (Berl.) 43: 233-248.

Percival, M. S. 1962. Types of nectar in Angiosperms. New Phytol. 60: 235-281.

. 1965. Floral biology. Pergamon Press, Oxford.

Pickett, C. H., AND W. D. Clark. 1979. The extrafloral nectaries of Opuntia acanthocarpa (Cactaceae). Amer. J. Bot. 66: 618-625.

Proctor, M., AND P. Yeo. 1973. The pollination of flowers. Collins, London.

Putman, W. L. 1963. Nectar of peach leaf glands as insect food. Can. Entomol. 95: 108-109.

Schubart, H. O. R., AND A. B. Anderson. 1978. Why don't ants visit flowers? A reply to D. H. Janzen. Biotropica 10: 310-311.

Tilman, D. 1978. Cherries, ants and tent caterpillars: timing of nectar production in relation to susceptibility of caterpillars to ant predation. Ecology 59: 686-692. 